\title{
Effect of Mineral Fertilization and Irrigation on Sunflower Yields
}

\author{
Lucia Helena Garófalo Chaves ${ }^{1 *}$, Danila Lima Araujoํㅜ, Hugo Orlando Carvallo Guerra ${ }^{1}$, \\ Walter Esfrain Pereira ${ }^{2}$ \\ ${ }^{1}$ Federal University of Campina Grande, Avenue Aprigio Veloso, Campina Grande, Brazil \\ ${ }^{2}$ Federal University of Paraiba, Campus II, Areia, Brazil \\ Email: Ihgarofalo@hotmail.com
}

Received 24 September 2014; accepted 6 April 2015; published 13 April 2015

Copyright (C) 2015 by authors and Scientific Research Publishing Inc.

This work is licensed under the Creative Commons Attribution International License (CC BY).

http://creativecommons.org/licenses/by/4.0/

(c) () Open Access

\begin{abstract}
Among the cultures used for the production of biofuels, the sunflower is one of the most important. Although some information exists, the water and nutritional needs of sunflower in the north east of Brazil are not well known. To fill knowledge gaps, an experiment was carried out to evaluate the effect of nitrogen (N), phosphorus (P), potassium (K) fertilization and available soil water (ASW) on sunflower yields. The sunflower cultivar Embrapa 122-V2000 was subjected to 44 treatments on a completely randomized design generated by the Baconian Matrix with four rates of $N(0,60,80$ and $\left.100 \mathrm{~kg} \cdot \mathrm{ha}^{-1}\right)$, four rates of $\mathrm{P}_{2} \mathrm{O}_{5}\left(0,80,100\right.$ and $\left.120 \mathrm{~kg} \cdot \mathrm{ha}^{-1}\right)$, four rates of $\mathrm{K}_{2} \mathrm{O}(0,80,100$ and $\left.120 \mathrm{~kg} \cdot \mathrm{ha}^{-1}\right)$, and four available soil water (ASW) levels $(55 \%, 70 \%, 85 \%$ and $100 \%)$ replicated three times. Urea was used as a source of $\mathrm{N}$, triple super phosphate as $\mathrm{P}$ and potassium chloride as $\mathrm{K}$. In all the experimental units was applied $2 \mathrm{~kg} \cdot \mathrm{B} \cdot \mathrm{ha}^{-1}$ as boric acid. The components of production evaluated were dry matter of the head, total number of achenes, total achenes' weight and 1000 achenes' weight. The results of this research showed that nitrogen had a significant effect on the dry matter of the head, total number of achenes and total achenes' weight. Phosphorus affected all production components and potassium affected the total number and the weight of achenes. With the exception of the 1000 achenes' weight, all the production components of the sunflower increased with the increased ASW level influenced significantly at 0.01 level of probably the total number of achenes. The highest rates of $N, P$ and $K\left(100,120\right.$ and $120 \mathrm{~kg}^{-h} \mathrm{~h}^{-1}$, respectively) and $100 \%$ of available soil water produced the highest production.
\end{abstract}

\section{Keywords}

Water, Fertilizers, Yields, Oil Plants, Seeds

\footnotetext{
"Corresponding author.
}

How to cite this paper: Chaves, L.H.G., Araujo, D.L., Guerra, H.O.C. and Pereira, W.E. (2015) Effect of Mineral Fertilization and Irrigation on Sunflower Yields. American Journal of Plant Sciences, 6, 870-879. 


\section{Introduction}

Sunflower (Helianthus annuus L.) occupies a prominent place among oilseed crops, as it contributes approximately $12 \%$ to global edible oil production. Water and nutrients play an important role in improving seed yield and oil quality of sunflowers [1]. Application of fertilizers substantially increases sunflower growth and yields, however, additions of nitrogen $(\mathrm{N})$, phosphorus $(\mathrm{P})$ and potassium $(\mathrm{K})$ need to be optimized. In sunflowers, nutrient deficiency can result in up to $60 \%$ reduction in productivity [2]. The nutritional needs of sunflower are greater than many other crops like wheat, sorghum and corn, requiring higher amounts of $\mathrm{N}$ and other macronutrients [3].

The number of achenes per head is a reflection of action of $\mathrm{N}$ in critical early stages of flowering in sunflower development. The potential number of flowers is determined very early, and subsequently affects the number of achenes and head diameter [4]. Head diameter is one of the morphological characteristics most affected by addition of $\mathrm{N}$, showing increases even with small $\mathrm{N}$ doses $\left(25 \mathrm{~kg} \cdot \mathrm{N} \cdot \mathrm{ha}^{-1}\right)$. However, this increase in head diameter does not continue with further increases of N. Sachs et al. [5] observed an increase of achenes productivity with $\mathrm{N}$ doses up to $55 \mathrm{~kg} \cdot \mathrm{N} \cdot \mathrm{ha}^{-1}, 41 \mathrm{~kg} \mathrm{ha}^{-1}$ of $\mathrm{K}_{2} \mathrm{O}$ and $46 \mathrm{~kg} \cdot \mathrm{ha}^{-1}$ of $\mathrm{P}_{2} \mathrm{O}_{5}$. The achenes' oil content increased with the application of $\mathrm{K}_{2} \mathrm{O}$ and $\mathrm{P}_{2} \mathrm{O}_{5}$ and the protein content decreased with increasing $\mathrm{K}_{2} \mathrm{O}$ application.

Shortage of water, which is the most important component of life, limits plant growth and crop productivity, particularly in arid regions. Sunflower is commonly regarded as a plant that is tolerant to drought and it uses water efficiently. Nevertheless, the crop consumes a large amount of total water due to the fact that it produces high yields and a large vegetative bulk. It also has a long growing period coinciding with the warm months of spring and summer. Water stress on sunflower reduces plant height, root length, stomata number and causes early flowering, early maturity and seed yield reduction. Drought adversely influenced leaf area leaf area, days to maturity, leaf diameter, 1000-achene weight and achene yield per plant [6].

The present research aimed to investigate the yield of sunflower affected by the interaction between NPK fertilization treatments and irrigation regimes under semiarid Brazilian conditions.

\section{Materials and Methods}

The experiment was carried out from March to July 2011 under greenhouse conditions at the Agricultural Engineering Department of the Federal University of Campina Grande, Paraiba State, Brazil.

The sunflower cultivar used was the Embrapa 122-V2000. A total of 44 treatments on a completely randomized design generated by the Baconian Matrix (Table 1) with four doses of $\mathrm{N}\left(0,60,80\right.$ and $\left.100 \mathrm{~kg} \cdot \mathrm{ha}^{-1}\right)$, four of $\mathrm{P}_{2} \mathrm{O}_{5}\left(0,80,100\right.$ and $\left.120 \mathrm{~kg} \cdot \mathrm{ha}^{-1}\right)$, four of $\mathrm{K}_{2} \mathrm{O}\left(0,80,100\right.$ and $\left.120 \mathrm{~kg} \cdot \mathrm{ha}^{-1}\right)$, four available soil water (ASW) levels $(55 \%, 70 \%, 85 \%$ and 100\%) and three replicates resulting in 132 experimental units. Urea was used as a source of $\mathrm{N}$; triple super phosphate as $\mathrm{P}$ and potassium chloride as $\mathrm{K}$. In the soil in all the experimental units was applied, as pure solution, $2 \mathrm{~kg} \cdot \mathrm{B} \cdot \mathrm{ha}^{-1}$ as boric acid.

Each experimental unit consisted of a plastic pot filled with $32 \mathrm{~kg}$ of an Alfisol with the following attributes using the procedures recommended by [7]: sand $=553.40 \mathrm{~g} \cdot \mathrm{kg}^{-1} ; \mathrm{silt}=117.30 \mathrm{~g} \cdot \mathrm{kg}^{-1} ; \mathrm{clay}^{2}=329.30 \mathrm{~g} \cdot \mathrm{kg}^{-1} ; \mathrm{pH}$ $\left(\mathrm{H}_{2} \mathrm{O}\right)=6.6 ; \mathrm{Ca}^{2+}=1.45 \mathrm{cmol}_{\mathrm{c}} \cdot \mathrm{kg}^{-1} ; \mathrm{Mg}^{2+}=1.65 \mathrm{cmol}_{\mathrm{c}} \cdot \mathrm{kg}^{-1} ; \mathrm{Na}=0.17 \mathrm{cmol}_{\mathrm{c}} \cdot \mathrm{kg}^{-1} ; \mathrm{K}^{+}=0.21 \mathrm{cmol}_{\mathrm{c}} \cdot \mathrm{kg}^{-1} ; \mathrm{H}^{+}+$ $\mathrm{Al}^{3+}=0.79 \mathrm{cmol}_{\mathrm{c}} \cdot \mathrm{kg}^{-1}$; organic matter $=22.2 \mathrm{~g} \cdot \mathrm{kg}^{-1} ;$ Available P $($ Mehlich $)=8.1 \mathrm{mg} \cdot \mathrm{kg}^{-1}$.

Soil water content was monitored daily at three depth intervals: $0-10,10-20$ and $20-30 \mathrm{~cm}$, using a Frequency Domain Reflectometry (FDR) segmented probe, inserted into the soil through an access tube installed in the pots. The volume of water required to maintain ASW for each treatment was calculated based the difference between field capacity and the permanent wilting point, and the FDR measurements. Irrigation was performed daily.

Five sunflower seeds were sown directly in the pots at a $2 \mathrm{~cm}$ depth. Twenty days after sowing, seedlings were thinned to one plant per pot.

When the experiment was finalized, plants were harvested and measured for dry matter (grams) of the head (DMH), total number of achenes (TNA), total weight (grams) achenes (TWA) and 1000 achenes weight (W1000A).

The results were analyzed statistically through the analyses of variance (ANOVA) described by [8], using SAEG software [9]. 
Table 1. Nitrogen $(\mathrm{N})$, phosphorus $\left(\mathrm{P}_{2} \mathrm{O}_{5}\right)$, potassium $\left(\mathrm{K}_{2} \mathrm{O}\right)$ and available soil water levels generated by the Baconian matrix.

\begin{tabular}{|c|c|c|c|c|c|c|c|c|c|}
\hline Treatments. & $\mathrm{N}$ & $\mathrm{P}_{2} \mathrm{O}_{5}$ & $\mathrm{~K}_{2} \mathrm{O}$ & Water & Treatments & $\mathrm{N}$ & $\mathrm{P}_{2} \mathrm{O}_{5}$ & $\mathrm{~K}_{2} \mathrm{O}$ & Water \\
\hline & & ------kg·ha & & $\%$ & & \multicolumn{3}{|c|}{----- kg·ha ${ }^{-1}----$} & $\%$ \\
\hline 1 & 0 & 0 & 0 & 55 & 23 & 0 & 0 & 0 & 85 \\
\hline 2 & 0 & 80 & 80 & 55 & 24 & 0 & 80 & 80 & 85 \\
\hline 3 & 80 & 80 & 80 & 55 & 25 & 80 & 80 & 80 & 85 \\
\hline 4 & 100 & 80 & 80 & 55 & 26 & 100 & 80 & 80 & 85 \\
\hline 5 & 60 & 0 & 80 & 55 & 27 & 60 & 0 & 80 & 85 \\
\hline 6 & 60 & 100 & 80 & 55 & 28 & 60 & 100 & 80 & 85 \\
\hline 7 & 60 & 120 & 80 & 55 & 29 & 60 & 120 & 80 & 85 \\
\hline 8 & 60 & 80 & 0 & 55 & 30 & 60 & 80 & 0 & 85 \\
\hline $9^{*}$ & 60 & 80 & 80 & 55 & $31^{*}$ & 60 & 80 & 80 & 85 \\
\hline 10 & 60 & 80 & 100 & 55 & 32 & 60 & 80 & 100 & 85 \\
\hline 11 & 60 & 80 & 120 & 55 & 33 & 60 & 80 & 120 & 85 \\
\hline 12 & 0 & 0 & 0 & 70 & 34 & 0 & 0 & 0 & 100 \\
\hline 13 & 0 & 80 & 80 & 70 & 35 & 0 & 80 & 80 & 100 \\
\hline 14 & 80 & 80 & 80 & 70 & 36 & 80 & 80 & 80 & 100 \\
\hline 15 & 100 & 80 & 80 & 70 & 37 & 100 & 80 & 80 & 100 \\
\hline 16 & 60 & 0 & 80 & 70 & 38 & 60 & 0 & 80 & 100 \\
\hline 17 & 60 & 100 & 80 & 70 & 39 & 60 & 100 & 80 & 100 \\
\hline 18 & 60 & 120 & 80 & 70 & 40 & 60 & 120 & 80 & 100 \\
\hline 19 & 60 & 80 & 0 & 70 & 41 & 60 & 80 & 0 & 100 \\
\hline $20^{*}$ & 60 & 80 & 80 & 70 & $42 *$ & 60 & 80 & 80 & 100 \\
\hline 21 & 60 & 80 & 100 & 70 & 43 & 60 & 80 & 100 & 100 \\
\hline 22 & 60 & 80 & 120 & 70 & 44 & 60 & 80 & 120 & 100 \\
\hline
\end{tabular}

"Reference level used by the sunflower growers of the region.

\section{Results and Discussion}

The ANOVA results are presented in Table 2. The results indicate that N, P and ASW had a significant effect on dry matter of the head (DMH) at $1 \%$ level of probability (Table 2) corroborating [10].

For plants treated with $\mathrm{N}$ the DMH increased with increasing $\mathrm{N}$ rate whose data were fitted to a quadratic regression model (Figure 1(a)). It is observed that the highest value of this variable (28 g) was registered for the highest dose of $\mathrm{N}\left(100 \mathrm{~kg} \cdot \mathrm{ha}^{-1}\right) 25 \%$ higher than the DMH found for the control treatment. The DMH was also influenced significantly by increasing $\mathrm{P}$ doses, and these results were fitted to a quadratic regression model (Figure 1(b)). The highest value of this variable $(31 \mathrm{~g})$ was obtained with the highest dose of $\mathrm{P}\left(120 \mathrm{~kg} \cdot \mathrm{ha}^{-1}\right)$ showing a superiority of $556 \%$ when compared with the reference level. The results corroborate [11] and [12] who found an increase of the DMH of sunflower cv. Embrapa 122/V-2000 with increasing N doses and ASW.

Potassium rates did not affect the DMH values (Table 2). These results disagree with those results found by [6] and [12] who found a positive significant effect of $\mathrm{K}$ on $\mathrm{DMH}$.

The DMH increased linearly with increasing ASW from 18 to $24 \mathrm{~g}$, for the lowest (55\%) to the greatest ASW doses (100\%), respectively (Figure 2). Guedes Filho et al. [11] observed an increase of 43\% in DMH when 


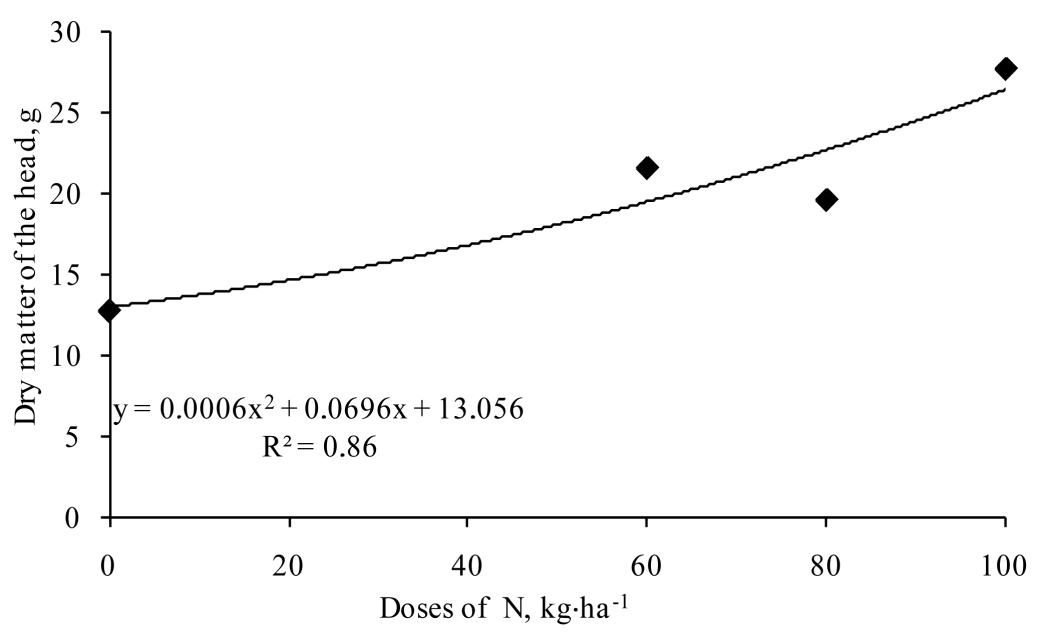

(a)

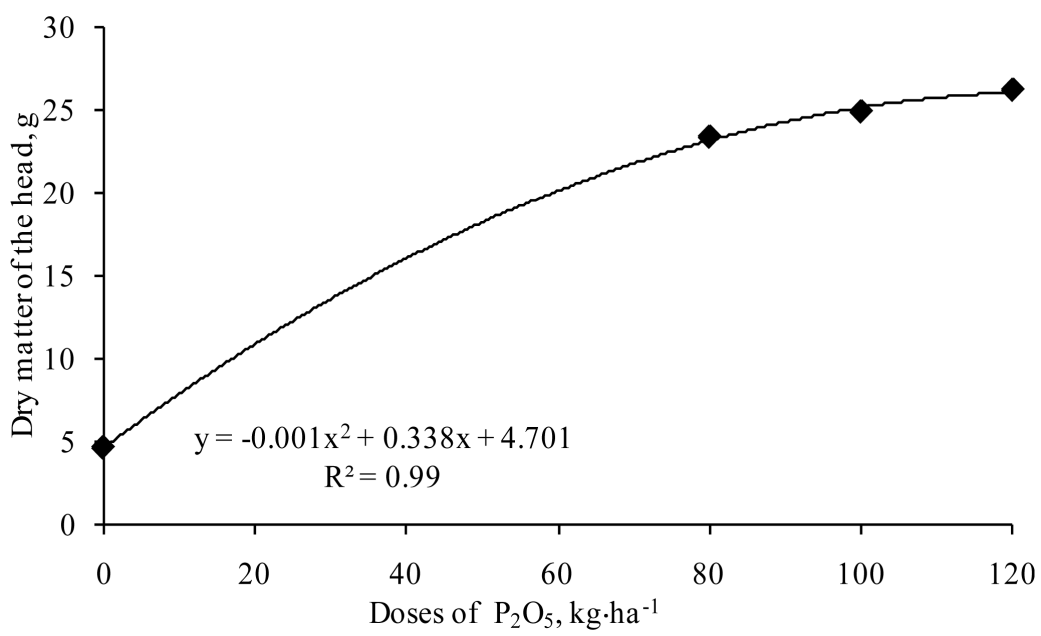

(b)

Figure 1. Regression curves for the relations $\mathrm{N}$ and $\mathrm{P}$ versus DMH.

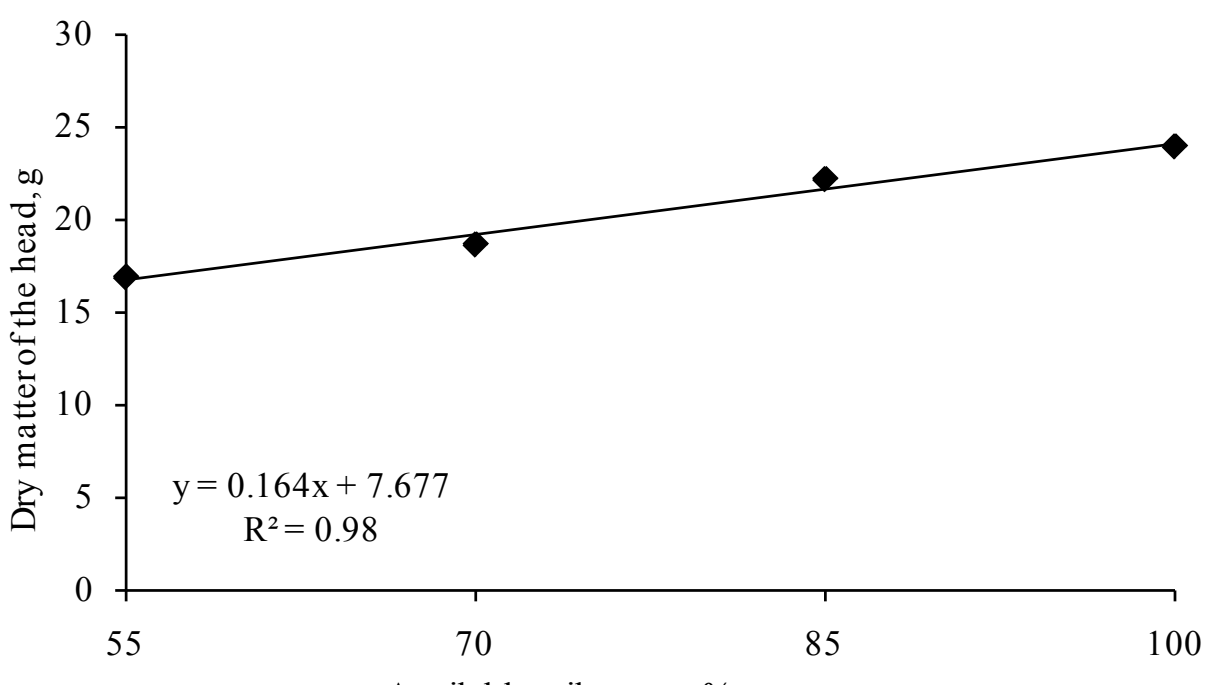

Available soil water, $\%$

Figure 2. Regression curve for the relation available soil water content $\times$ dry matter of the head. 
Table 2. Analysis of variance for dry matter of the head (DMH), total achenes' number (TAN), total achenes' weight (TWA) and 1000 achenes' weight (W1000A) for different levels of N, P, K and ASW.

\begin{tabular}{|c|c|c|c|c|c|c|c|c|c|}
\hline Source & DF & Mean square & $\operatorname{Pr}>F$ & Mean square & $\operatorname{Pr}>\mathrm{F}$ & Mean square & $\operatorname{Pr}>\mathrm{F}$ & Mean square & $\operatorname{Pr}>F$ \\
\hline & & \multicolumn{2}{|c|}{ DMH } & \multicolumn{2}{|c|}{ TAN } & \multicolumn{2}{|c|}{ TWA } & \multicolumn{2}{|c|}{ W1000A } \\
\hline $\mathrm{N}$ & 3 & 141.76 & $<0.0001$ & 77234.76 & $<0.0001$ & 51.95 & 0.0013 & 618.67 & 0.0625 \\
\hline $\mathrm{P}$ & 3 & 1682.16 & $<0.0001$ & 423580.92 & $<0.0001$ & 669.36 & $<0.0001$ & 5869.42 & $<0.0001$ \\
\hline $\mathrm{K}$ & 3 & 5.40 & 0.7513 & 5677.88 & 0.0009 & 27.59 & 0.0338 & 270.98 & 0.3511 \\
\hline ASW & 3 & 61.78 & 0.0047 & 50590.70 & 0.0020 & 46.66 & 0.0026 & 54.61 & 0.8804 \\
\hline $\mathrm{N}^{*} \mathrm{ASW}$ & 9 & 19.08 & 0.1894 & 32852.11 & 0.0010 & 15.84 & 0.0924 & 249.73 & 0.4311 \\
\hline $\mathrm{P}^{*} \mathrm{ASW}$ & 9 & 25.66 & 0.0593 & 14096.31 & 0.1659 & 24.62 & 0.0079 & 252.92 & 0.4211 \\
\hline $\mathrm{K}^{*} \mathrm{ASW}$ & 9 & 18.56 & 0.2063 & 7348.53 & 0.6415 & 5.33 & 0.8070 & 250.49 & 0.4287 \\
\hline Contrast & $\mathrm{DF}$ & & & & & & & & \\
\hline $\mathrm{N}$ linear & 1 & 109.05 & 0.0054 & 207053.43 & $<0.0001$ & 142.18 & 0.0002 & 43.10 & 0.6760 \\
\hline $\mathrm{N}$ quadratic & 1 & 177.65 & 0.0004 & 1227.04 & 0.7202 & 0.75 & 0.7745 & 229.97 & 0.3353 \\
\hline $\mathrm{P}$ linear & 1 & 2417.57 & $<0.0001$ & 556461.89 & $<0.0001$ & 1031.08 & $<0.0001$ & 8932.15 & $<0.0001$ \\
\hline $\mathrm{P}$ quadratic & 1 & 1139.87 & $<0.0001$ & 318864.65 & $<0.0001$ & 644.27 & $<0.0001$ & 2925.41 & 0.0008 \\
\hline $\mathrm{K}$ linear & 1 & 2.22 & 0.6850 & 207053.43 & $<0.0001$ & 142.18 & 0.0002 & 43.10 & 0.6760 \\
\hline K quadratic & 1 & 11.04 & 0.3664 & 1227.04 & 0.7202 & 0.75 & 0.7745 & 229.97 & 0.3353 \\
\hline ASW linear & 1 & 124.20 & 0.0030 & 62694.06 & 0.0118 & 101.99 & 0.0012 & 130.48 & 0.4675 \\
\hline ASW quadratic & 1 & 5.39 & 0.5275 & 87700.72 & 0.0031 & 17.67 & 0.1677 & 26.92 & 0.7411 \\
\hline $\mathrm{N} \times \mathrm{ASW}$ & 1 & 51.84 & 0.0522 & 53772.80 & 0.0195 & 21.65 & 0.1272 & 555.46 & 0.1357 \\
\hline $\mathrm{P} \times \mathrm{ASW}$ & 1 & 0.0007 & 0.9941 & 6512.35 & 0.4100 & 9.58 & 0.3085 & 359.46 & 0.2290 \\
\hline $\mathrm{K} \times \mathrm{ASW}$ & 1 & 19.93 & 0.2258 & 3238.75 & 0.5608 & 6.20 & 0.4122 & 591.56 & 0.1238 \\
\hline
\end{tabular}

ASW was increased from 55\% to $100 \%$. Similarly [13] observed that the level of ASW influenced the DMH linearly at $1 \%$ probability. The higher dry matter accumulation may be a reflection of a greater ion absorption in soil, since the increase in soil moisture on the development of sunflower crop can be significant in nutrient uptake by plants.

The total number of achenes (TAN) was significantly affected, at $1 \%$ level of probability, by the increase of N, $\mathrm{P}$ and $\mathrm{K}$ doses and available soil water. The interaction among N and ASW at $1 \%$ level of probability was also significant (Table 2) corroborating [12].

The increase of the number of achenes with the $\mathrm{N}$ doses was fitted to a linear model as observed in Figure 3(a). The greatest TAN was obtained, thus, with the highest $\mathrm{N}$ doses.

The effect of $\mathrm{P}$ on the TAN was fitted to a quadratic model (Figure 3(b)) verifying the greatest achene number (416) at $80 \mathrm{~kg} \cdot \mathrm{P} \cdot \mathrm{ha}^{-1}$. This kind of adjustment was also reported by [14] and [15]. The response of achene number to the $\mathrm{K}$ was also fitted to a quadratic model (Figure 4(a)) verifying the greatest achene number (506) for the $120 \mathrm{~kg} \cdot \mathrm{K} \cdot \mathrm{ha}{ }^{-1}$.

The increase in available soil water content increased, in a quadratic manner, the achene number from 301 to 448 when water increased from $55 \%$ to $100 \%$ ASW, an increase of $52.30 \%$ (Table 2). Otherwise, [11] found a quadratic effect producing above 600 achenes with $100 \%$ level available soil water.

The effect of ASW on the sunflower is similar to other studies [12] [16]-[18]. Figure 4(b) shows an increase of the TAN with the ASW in a quadratic model, obtaining the highest number of achenes for the highest level of water.

The interaction among $\mathrm{N}$ and the available soil water content on TAN was significant to the $1 \%$ level of probability (Table 2). Figure 5 presents the cited interaction. It is observed that in general, the TAN increased 


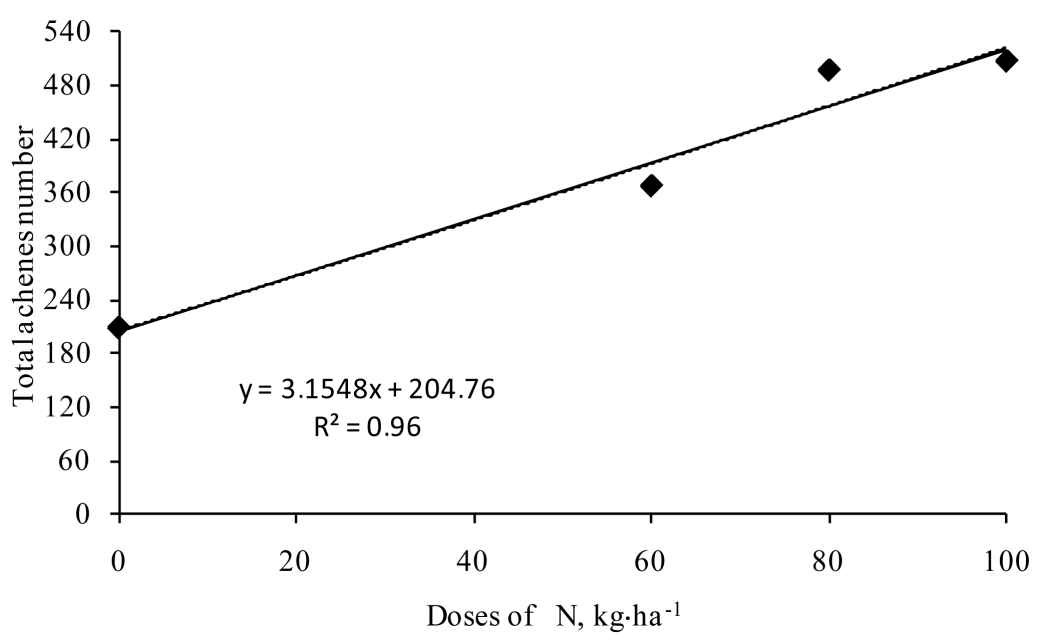

(a)

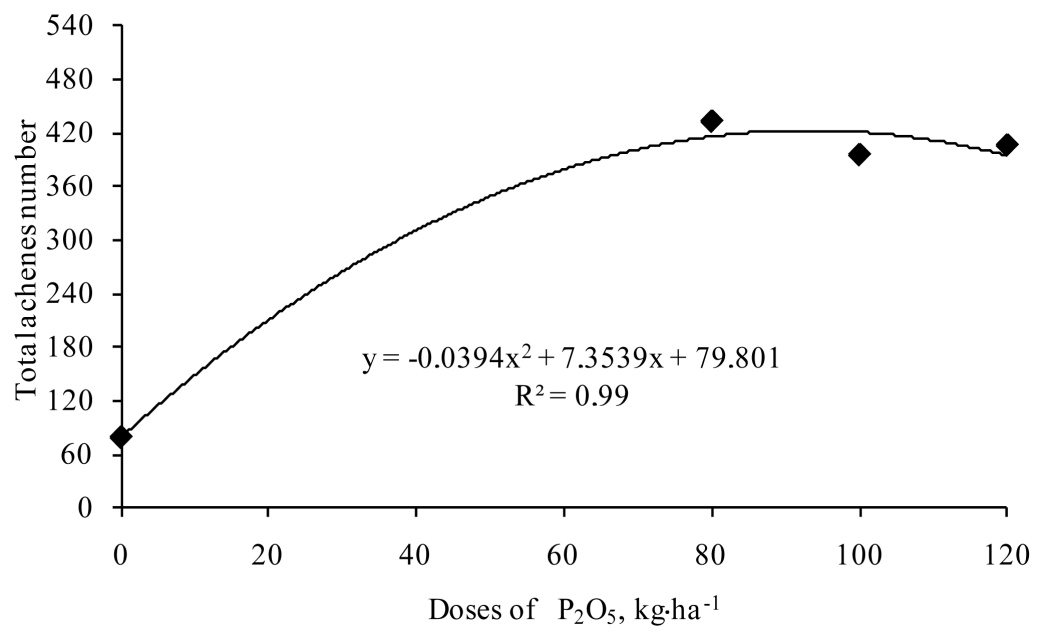

(b)

Figure 3. Regression curves for the relations $\mathrm{N} \times$ total achenes' number and $\mathrm{P} \times$ total achenes' number.

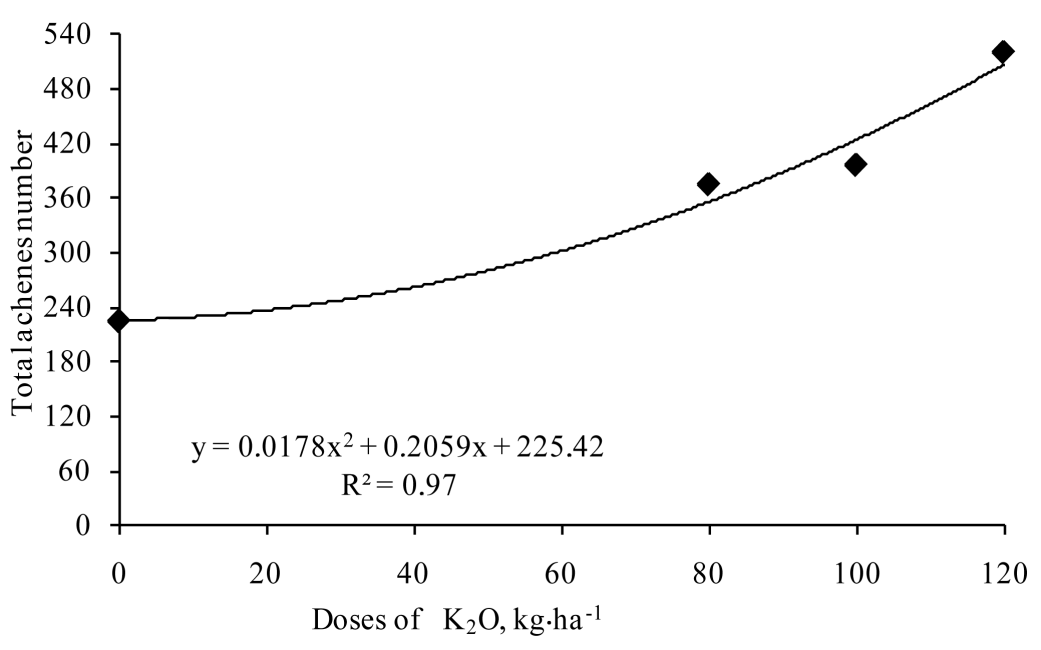

(a) 


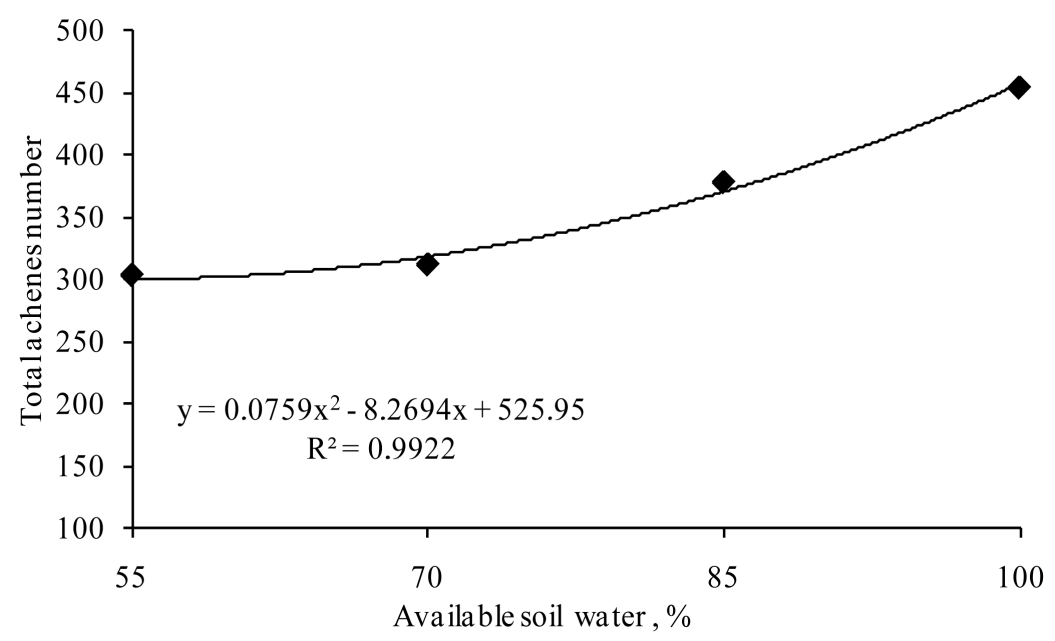

(b)

Figure 4. Regression curves for the relations $\mathrm{K} \times \mathrm{TAN}$ and ASW $\times \mathrm{TAN}$.

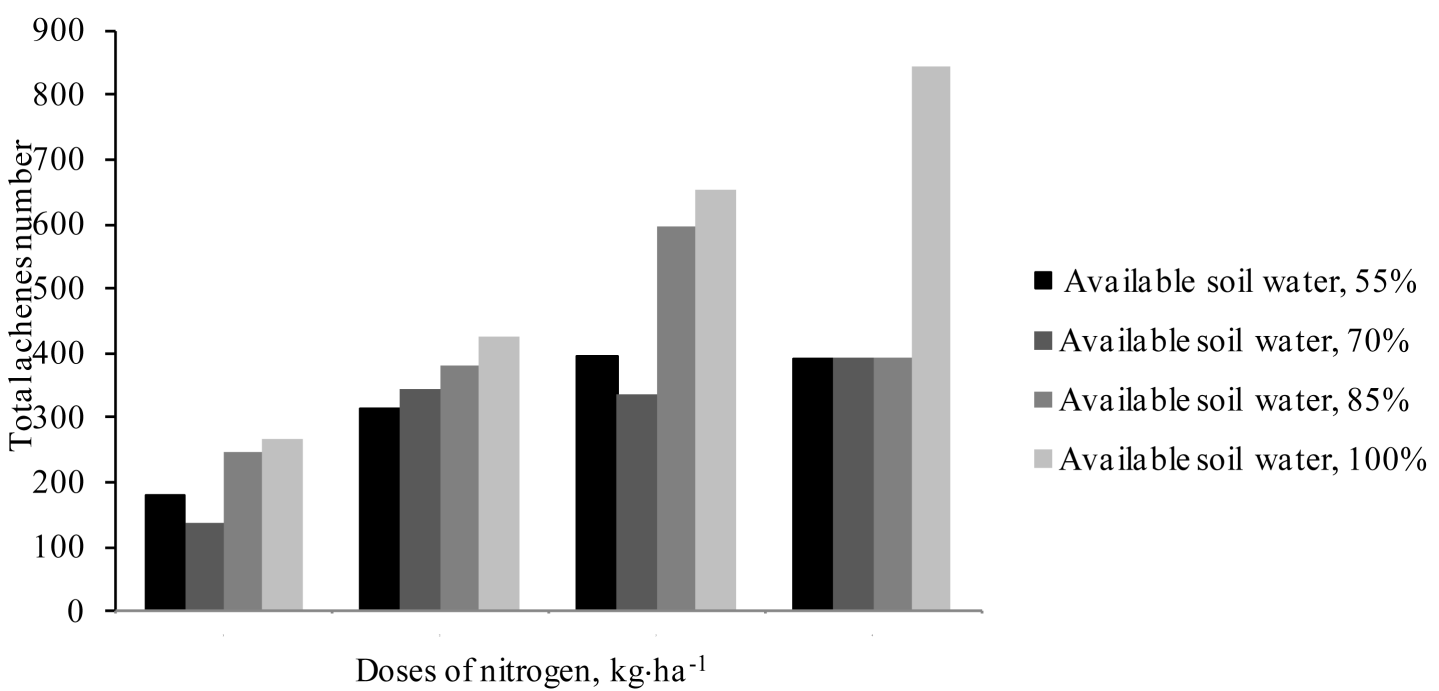

Figure 5. Interaction among $\mathrm{N}$ and the ASW on TAN.

with the $\mathrm{N}$ application and with the ASW. Thus the highest total number of achenes (844) was obtained with the highest $\mathrm{N}$ application $\left(100 \mathrm{~kg} \cdot \mathrm{ha}^{-1}\right)$ and the highest ASW (100\%).

The total achenes' weight was significantly influenced by increasing N, P, K rates and the ASW (Table 2). Total achenes' weight increased with $\mathrm{N}$ and $\mathrm{P}$ treatments, the data was adjusted to a linear and quadratic regression model, respectively (Figure 6(a) and Figure 6(b), respectively). Analyzing Figure 6(a), it is observed that

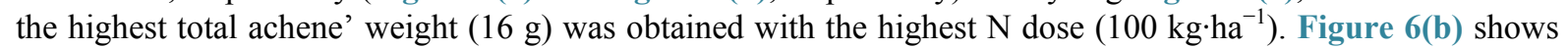
that the highest total achene' weight $(16 \mathrm{~g})$ was obtained with the highest $\mathrm{P}$ doses $\left(96 \mathrm{~kg} \cdot \mathrm{ha}^{-1}\right)$. These highest weights were $136 \%$ and $728 \%$ superior to the control treatment, respectively.

The TWA increased linearly with increasing K (Figure 7(a)) verifying the greatest achene weight (15.67 g) for the $120 \mathrm{~kg} \cdot \mathrm{P} \cdot \mathrm{ha}^{-1}$. The ASW treatments increased the total achenes weight linearly obtaining 8.94 and 15.22 $\mathrm{g}$ for the lowest and highest treatment, respectively. There was an increase of $70.25 \%$ between the lowest and highest water treatments.

The 1000 achenes' weight of sunflower was only affected by the $\mathrm{P}$ application, at the $1 \%$ level of probability. The regression was adjusted to a quadratic model (Figure 8), verifying an increase of the 1000 achenes' weight with $\mathrm{P}$ application and therefore, the greatest value for the treatment of $120 \mathrm{~kg} \cdot \mathrm{P} \cdot \mathrm{ha}^{-1}(60 \mathrm{~g})$. 


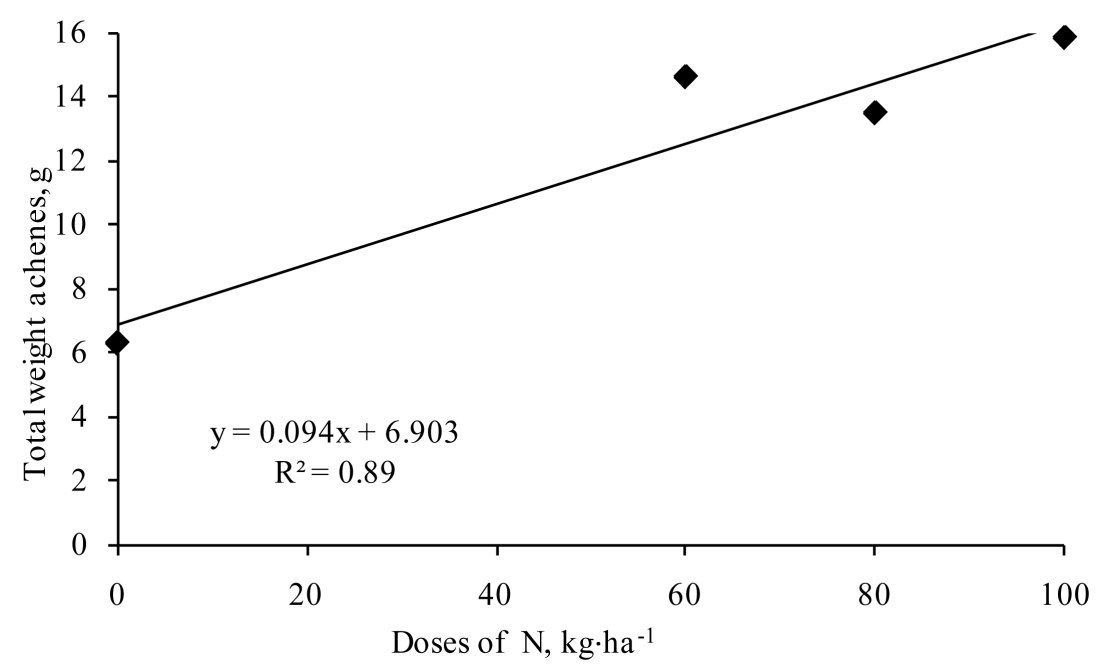

(a)

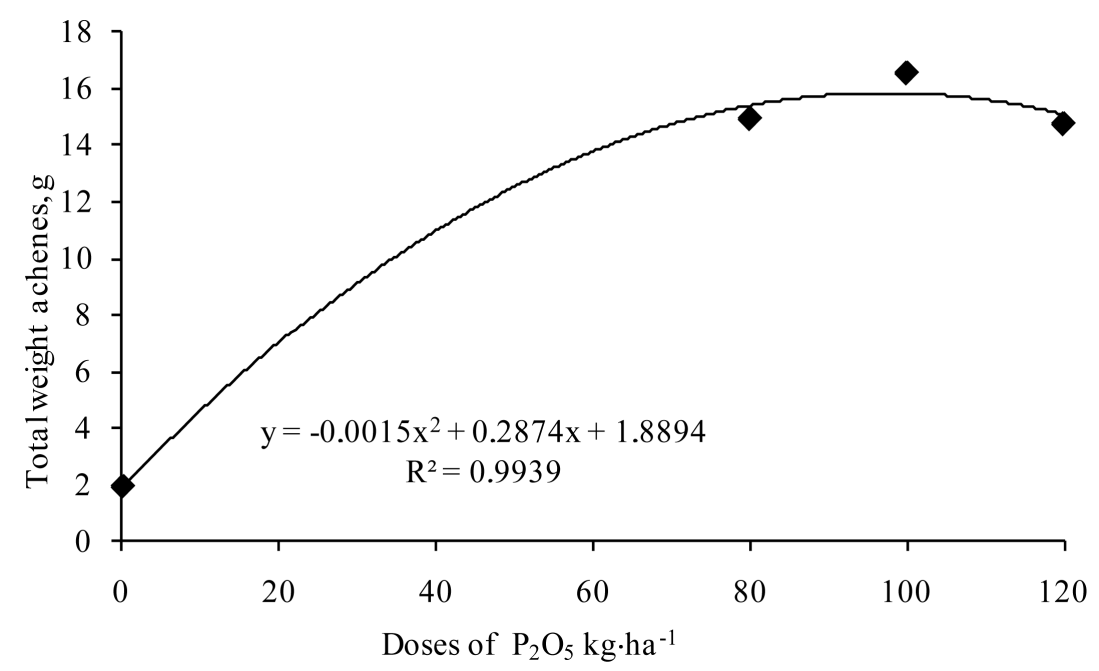

(b)

Figure 6. Regression curves for the relations Nx TWA and P $\times$ TWA.

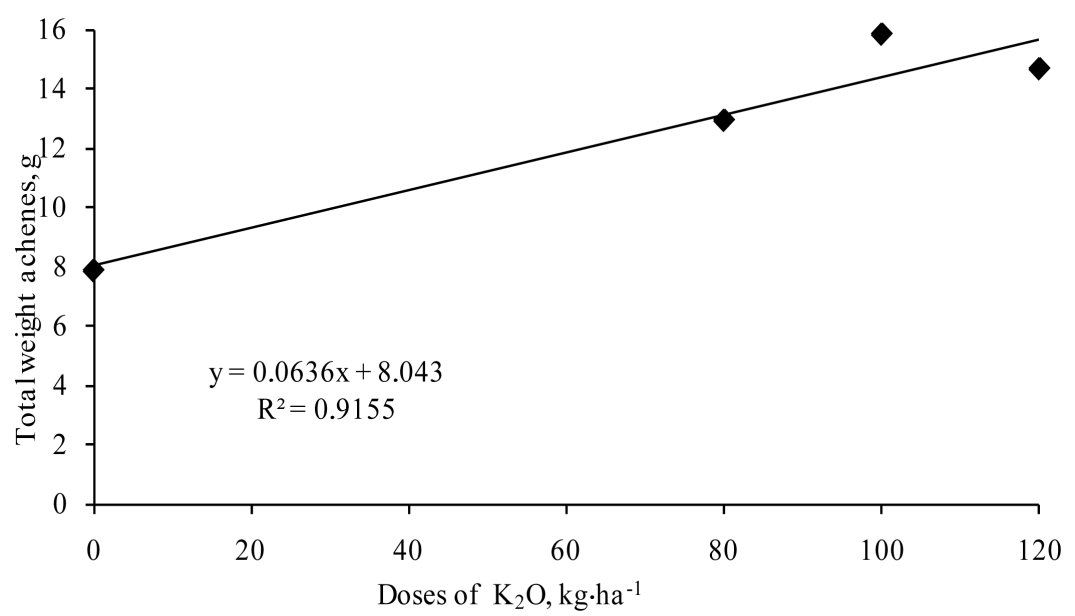

(a) 


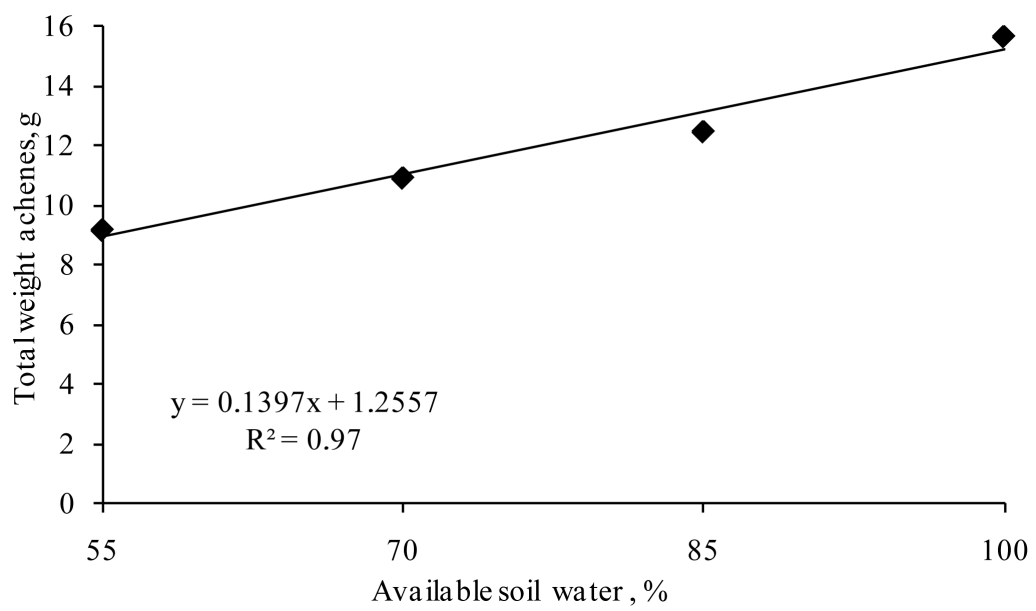

(b)

Figure 7. Regression curves for the relation $\mathrm{K} \times$ total achenes' weight (a) and ASW $\times$ total achenes' weight (b).

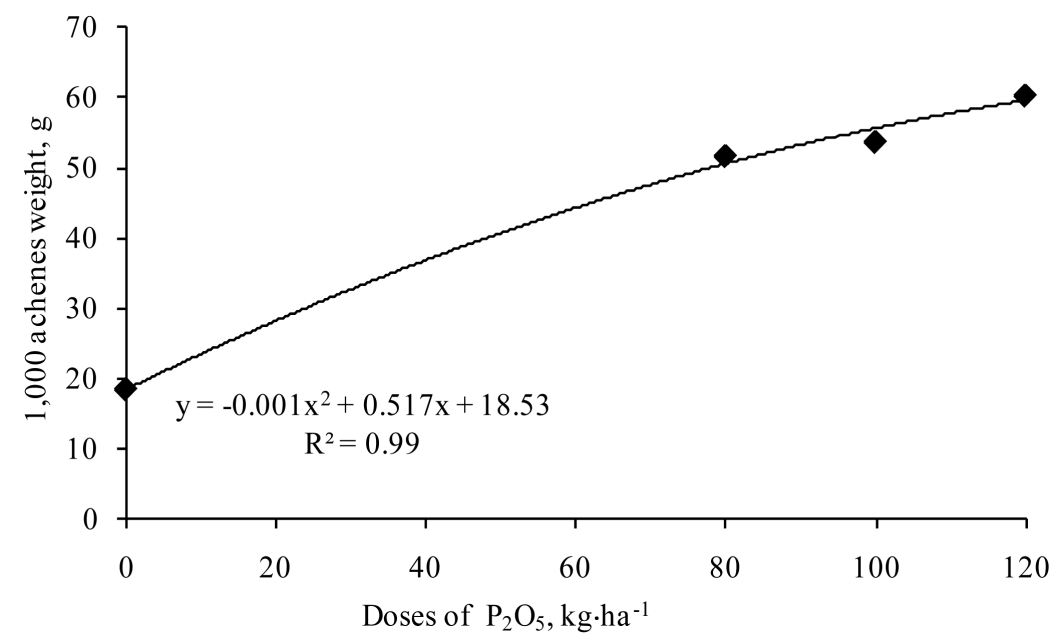

Figure 8. Regression curve for the relation $\mathrm{P} \times 1000$ achenes' weight.

\section{Conclusions}

The dry matter of the head, the total achenes' number and the total achenes' weight increased significantly with the nitrogen doses applied.

All the sunflower variables studied increased significantly with the phosphorus doses applied.

The total achenes' number and the total achenes' weight increased significantly with the potassium doses applied.

With the exception of the 1000 achenes' weight, whose effect was not significant, all the production components of the sunflower increased with the available water in the soil.

The interaction between $\mathrm{N}$ and the available soil water content was significant only for the TAN. It increased with the $\mathrm{N}$ application and with ASW.

The highest rates of N, P, and K (100, 120 and $120 \mathrm{~kg} \cdot \mathrm{ha}^{-1}$, respectively) and the $100 \%$ available soil water produced the highest production.

\section{Acknowledgements}

Thanks to the Coordination of Improvement of Higher Education (CAPES) for the scholarship award to the 
second author at the Graduate School.

\section{References}

[1] Hussain, M.K., Rasul, E. and Ali, S.K. (2000) Growth Analysis of Sunflower (Helianthus annuus L.) under Drought Conditions. International Journal of Agriculture and Biology, 2, 136-140.

[2] Biscaro, G.A., Machado, J.R., Tosta, M.S., Mendonça, V., Soratto, R.P. and Carvalho, L.A. (2008) Nitrogen Side Dressing Fertilization in Irrigated Sunflower under Conditions of Cassilândia-MS. Ciência e Agrotecnologia, 32, 13661373. http://dx.doi.org/10.1590/S1413-70542008000500002

[3] Vigil, M.F. (2000) Fertilization in Dryland Cropping Systems: A Brief Overview Central Great Plains. Research Station-USDA-ARS.

[4] Zagonel, J. and Mundstock, C.M. (1991) Nitrogen Rates and Side-Dress Timing on Two Sunflower Cultivars. Pesquisa Agropecuária Brasileira, 26, 1487-1492.

[5] Sachs, L.G., Portugal, A.P., Prudencio-Ferrreira, S.H., Ida, E.I. and Sachs, P.J. (2006) Efeito de NPK na produtividade e componentes químicos do girassol. Semina: Ciências Agrárias, 27, 533-546. http://dx.doi.org/10.5433/1679-0359.2006v27n4p533

[6] Bakht, J., Shafi, M., Yousaf, M., Raziuddin R. and Khan, M.A. (2010) Effect of Irrigation on Physiology and Yield of Sunflower Hybrids. Pakistan Journal of Botany, 42, 1317-1326.

[7] EMBRAPA, Centro Nacional de Pesquisa de Solos (1997) Manual de métodos de analise de solo. 2nd Edition, rev. atual, Embrapa, Rio de Janeiro. ISBN-85-85864-03-6.

[8] Ferreira, D.F. (2000) Sistema de análises de variância para dados balanceados. UFLA, Lavras (SISVAR 4. 1. Pacote computacional).

http://www.scielo.br/scielo.php?script=sci nlinks\&ref=000117\&pid=S0100-2945200900030002000012\&lng=en

[9] Euclides, R.F. (1997) Manual de utilização do programa SAEG: sistema para análises estatísticas e genéticas. 2nd Edition, UFV, Viçosa. http://www.scielo.br/scielo.php?script=sci_nlinks\&ref=000084\&pid=S0100-204X200100020001800012\&lng=en

[10] Silva, P.C.C., Couto, J.L. and Santos, A.F. (2010) Absorção dos íons amônio e nitrato e seus efeitos no desenvolvimento do girassol em solução nutritiva. Revista de Biologia e Ciência da Terra, 10, 97-104.

[11] Guedes Filho, D.H., Chaves, L.H.G., Campos, V.B., Santos Júnior, A. and Oliveira, J.T.L. (2011) Production of Sunflower and Biomass Depending on Availables Oil Water and Nitrogen Levels. Iranica Journal of Energy and Environment, 2, 313-319.

[12] Chaves, L.H.G., Guerra, H.O.C., Campos, V.B., Pereira, W.E. and Ribeiro, P.H.P. (2014) Biometry and Water Consumption of Sunflower as Affected by NPK Fertilizer and Available Soil Water Content under Semiarid Brazilian Conditions. Agricultural Sciences, 5, 668-676.

[13] Oliveira, J.T.L., Chaves, L.H.G., Campos, V.B.J., Santos Júnior, A. and Guedes Filho, D.H. (2012) Fitomassa de girassol cultivado sob adubação nitrogenada e níveis de água disponível no solo. Revista Brasileira de Agricultura Irrigada, 6, 23-32. http://dx.doi.org/10.7127/rbai.v6n100077

[14] Sadiq, S.A., Shahid, M., Jan, A. and Noor-Ud-Din, S. (2000) Effect of Various Levels of Nitrogen, Phosphorus, Potassium (NPK) on Growth, Yield, Yield Components of Sunflower. Pakistan Journal of Biological Sciences, 3, 338-339. http://dx.doi.org/10.3923/pjbs.2000.338.339

[15] Gerendás, J., Abbadi, J. and Sattelmacher, B. (2008) Potassium Efficiency of Safflower (Carthamus tinctoriusL.) and Sunflower (Helianthus annuus L.). Journal of Plant Nutrition and Soil Science, 171, 431-439. http://dx.doi.org/10.1002/jpln.200720218

[16] Kakar, A.A. and Soomro, A.G. (2001) Effect of Water Stress on the Growth, Yield and Oil Content of Sunflower. Pakistan Journal of Agricultural Science, 38, 73-74.

[17] Bajehbaj, A.A. (2010) Effects of Water Limitation on Grain and Oil Yields of Sunflower Cultivars. Journal of Food, Agriculture and Environment, 8, 98-101.

[18] El Naim, A.M. and Ahmed, M.F. (2010) Effect of Irrigation Intervals and Inter-Row Spacing on Yield, Yields Components and Water Use Efficiency of Sunflower (Helianthus annuus L). Journal of Applied Sciences Research, 6, $1446-1451$. 